\title{
Pengaruh Keuangan Inklusif Terhadap Kredit yang Disalurkan pada Sektor Usaha Mikro, Kecil dan Menengah di Indonesia
}

\author{
Obaid M Fahmy* \\ Universitas Tanjungpura \\ M. Rustam \\ Universitas Tanjungpura \\ Evi Asmayadi \\ Universitas Tanjungpura
}

\begin{abstract}
This research is a quantitative study which aims to find out the effect of financial inclusion (banking access dimension and banking service usage dimension) on loans channeled to the Micro Small and Medium Sized Enterprises (MSMEs) sector in Indonesia. The variables used in this research were loans channeled to the MSMEs as dependent variable, and successively banking access dimension and banking service usage dimension as the independent variables. Using the purposive sampling method, a total of 33 provinces in Indonesia were selected as the samples with an observation period from 2010 to 2013. LDR (Loan to Deposit Ratio) and NPL (Non Performing Loan) were used as the control variables. Simultaneously there was a positive and significant effect of banking access dimension, banking service usage dimension, and LDR on loans channeled to the MSMEs sector, while NPL had a negative but insignificant effect.
\end{abstract}

Keywords : MSMEs, Financial Inclusion, Access Dimension, Usage Dimension, LDR, NPL

\section{LATAR BELAKANG}

Menurut survei Bank Dunia tahun 2010 dari sekitar 234,2 juta penduduk Indonesia, hampir separuh penduduk ( \pm 117 juta) tidak memiliki akses atas layanan lembaga keuangan formal. Dari jumlah itu, 35 juta orang hanya terlayani lembaga keuangan non formal seperti koperasi simpan-pinjam. Tapi ada sekitar 40 juta orang yang sama sekali tidak tersentuh layanan jasa keuangan dalam bentuk apapun. Setidaknya ada empat layanan jasa keuangan yang dianggap vital bagi kehidupan masyarakat, yakni penyimpanan dana, layanan kredit, layanan sistem pembayaran dan

\footnotetext{
* Korespondensi : Obaid M. Fahmy, Program Magister Manajemen, Universitas Tanjungpura, Jalan Imam Bonjol, Pontianak 78124, Indonesia. Alamat Email : obaid.fahmy@ gmail.com.
} 
asuransi termasuk dana pensiun. Keempat aspek dalam lingkup pengelolaan sistem keuangan ini menjadi prasyarat mendasar untuk menggapai kehidupan masyarakat yang lebih baik (Bank Indonesia, 2011).

Bila sebagian besar masyarakat sudah dapat memanfaatkan fasilitas jasa keuangan, dampak terhadap perekonomian akan sangat besar. Banyak fakta membuktikan bahwa ada hubungan sebab akibat yang kuat antara penguatan sistem keuangan dengan pertumbuhan ekonomi dan kemakmuran suatu negara. Sebagaimana yang ditunjukkan oleh penelitian Sarma (2012), bahwa rata-rata negara-negara maju yang tergabung dalam OECD (Organization for Economic Cooperation and Development) ternyata memiliki indeks keuangan inklusif yang lebih tinggi dibandingkan dengan negara non OECD. Semakin tinggi nilai indeks keuangan inklusif suatu negara maka semakin baik akses masyarakat di negara tersebut terhadap layanan lembaga keuangan formal.

Keuangan inklusif memiliki indikator yang multidimensi, beberapa faktor dominan sebagai keterwakilan dari indikator multidimesi disebut para peneliti sebelumnya seperti Sarma (2012) mengemukakan ada tiga dimensi yang dapat digunakan untuk mewakili multidimensi dari keuangan inklusif yaitu seperti aksesibilitas (accessibility), ketersediaan (availability) dan kemanfaatan (usage) dari layanan perbankan. Camara dan Tuesta (2014) menyebutkan bahwa tingkat keuangan inklusif ditentukan oleh tiga dimensi: Usage (pemanfaatan), Barriers (hambatan-hambatan), dan Access (akses). Adapun indikator Usage ada tiga menurut Camara \& Tuesta (2014) yakni : (a) Memiliki setidaknya satu produk keuangan. (b) Memiliki simpanan. (c) Memiliki pinjaman di lembaga keuangan formal. Indikator barriers diperoleh dari perspektif individu yang unbank (tidak berhubungan dengan bank).

Bank Indonesia juga mengemukakan faktor-faktor apa saja yang dominan didalam keuangan inklusif tersebut (Bank Indonesia, 2013) yakni : (1) Akses, dimensi yang digunakan untuk mengukur kemampuan penggunaan jasa keuangan formal, sehingga dapat dilihat terjadinya potensi hambatan untuk membuka dan mempergunakan rekening bank. Kemampuan nasabah mengakses perbankan dimanapun dan kapanpun menjadi salah satu elemen penting dalam keuangan inklusif. (2) Penggunaan (Usage), dimensi penggunaan adalah dimensi yang digunakan untuk mengukur kemampuan penggunaan aktual produk dan jasa keuangan, antara lain terkait keteraturan, frekuensi dan lama penggunaan. (3) Kualitas (Quality), dimensi untuk mengetahui apakah ketersediaan atribut produk dan jasa keuangan telah memenuhi kebutuhan pelanggan. The Alliance for Financial Inclusion (AFI) telah menyepakati prinsip-prinsip yang dipergunakan dalam menyusun indikator dari dimensi kualitas, meliputi ringkas (conciseness), spesifik (specifity), sederhana (simplicity), adanya perbaikan (improvement), dan kemudahan dari kacamata konsumen (client perspective). BI sendiri menggunakan survey financial literacy untuk pendekatan pada dimensi kualitas ini. 
Studi kali ini menggunakan pendekatan yang digunakan oleh Bank Indonesia dengan beberapa penyesuaian sesuai ketersediaan data. Penulis menganalisis pengaruh keuangan inklusif terhadap usaha mikro, kecil, dan menengah di Indonesia untuk melihat secara jelas kaitan antara keuangan inklusif terhadap usaha mikro, kecil, dan menengah dengan menggunakan dimensi akses dan dimensi penggunaan layanan perbankan sebagai variabel independen, LDR (loan to deposit ratio) dan NPL (Non Performing Loan) sebagai variabel kontrol. Adapun kredit yang disalurkan terhadap sektor UMKM sebagai variabel independen.

\section{KAJIAN LITERATUR}

\subsection{Pengertian Keuangan Inklusif}

Dalam Strategi Nasional Keuangan Inklusif (Bank Indonesia, Booklet Keuangan Inklusif 2014), keuangan inklusif didefinisikan sebagai hak setiap orang untuk memiliki akses dan layanan penuh dari lembaga keuangan secara tepat waktu, nyaman, informatif, dan terjangkau biayanya, dengan penghormatan penuh kepada harkat dan martabatnya. Layanan keuangan tersedia bagi seluruh segmen masyarakat, dengan perhatian khusus kepada orang miskin, orang miskin produktif, pekerja migran, dan penduduk di daerah terpencil.

Menurut Kelkar, Keuangan Inklusif adalah jasa keuangan yang diberikan meliputi akses layanan perbankan, kredit, simpanan, asuransi, fasilitas pembayaran dan pengiriman uang yang ditawarkan lembaga keuangan formal dengan biaya yang terjangkau terutama untuk kelompok masyarakat yang kurang beruntung dan berpenghasilan rendah yang cenderung terabaikan (Kelkar, 2009).

Sarma (2012) mendefinisikan keuangan inklusif sebagai sebuah proses yang menjamin kemudahan akses, ketersediaan, dan kemanfaatan dari sistem keuangan formal untuk semua anggota entitas ekonomi. Dari definisi mengenai keuangan inklusif di atas dapat disimpulkan bahwa keuangan inklusif adalah kemudahan akses kepada lembaga keuangan formal oleh seluruh lapisan masyarakat untuk pemberdayaan ekonomi.

\subsection{Dimensi Dalam Keuangan Inklusif}

Sarma (2012) mengemukakan ada tiga dimensi yang dapat digunakan untuk mewakili multidimensi dari keuangan inklusif yaitu aksesibilitas (accessibility), ketersediaan (availability) dan kemanfaatan (usage) dari layanan perbankan. Bank Indonesia juga mengemukakan faktor-faktor apa saja yang dominan didalam keuangan inklusif tersebut (Bank Indonesia, 2013) yakni: akses, penggunaan dan kualitas. 
Dimensi Akses digunakan untuk mengukur kemampuan penggunaan jasa keuangan formal, sehingga dapat dilihat terjadinya potensi hambatan untuk membuka dan mempergunakan rekening bank. Kemampuan nasabah mengakses perbankan dimanapun dan kapanpun menjadi salah satu elemen penting dalam keuangan inklusif. Indikator dimensi ini adalah : jumlah kantor bank per 100.000 penduduk dewasa, jumlah ATM per 100.000 penduduk dewasa, jumlah kantor bank per $1000 \mathrm{~km} 2$ dan jumlah ATM per $1000 \mathrm{~km} 2$.

Dimensi Penggunaan adalah dimensi yang digunakan untuk mengukur kemampuan penggunaan aktual produk dan jasa keuangan, antara lain terkait keteraturan, frekuensi dan lama penggunaan. Indikator yang dipergunakan dalam mengukur dimensi ini meliputi: jumlah rekening dana pihak ketiga (deposito, giro, dan tabungan) per 1000 penduduk dewasa, dan jumlah rekening kredit per 1000 peduduk dewasa.

Dimensi Kualitas adalah dimensi untuk mengetahui apakah ketersediaan atribut produk dan jasa keuangan telah memenuhi kebutuhan pelanggan. Pengukuran terhadap dimensi ini masih sukar untuk dilakukan dan saat ini beberapa lembaga internasional yang concern dalam pengembangan keuangan inklusif masih menyusun indikator yang tepat. BI sendiri menggunakan survey financial literacy tahun 2012 bekerjasama dengan Lembaga Demografi UI untuk pendekatan pada dimensi kualitas ini.

Camara dan Tuesta (2014) menyebutkan bahwa tingkat keuangan inklusif ditentukan oleh tiga dimensi: pemanfaatan (usage), hambatan-hambatan (barriers), dan akses (access). Adapun indikator usage menurut Camara dan Tuesta yakni memiliki setidaknya satu produk keuangan, memiliki simpanan, dan memiliki pinjaman di lembaga keuangan formal. Indikator barriers diperoleh dari perspektif individu yang unbank (tidak berhubungan dengan bank). Informasi hambatan yang dicatat seperti masalah jarak terhadap kantor lembaga keuangan formal, persyaratan dokumen yang sulit dipenuhi, keterjangkauan biaya, dan ketidakpercayaan terhadap sistem keuangan formal. Sedangkan untuk dimensi akses, dilihat dari indikator diantaranya jumlah atm dan jumlah kantor bank terhadap penduduk, juga jumlah atm dan kantor bank dalam radius tertentu.

\subsection{Kredit UMKM (Usaha Mikro, Kecil, dan Menengah)}

Kredit UMKM adalah kredit kepada debitur usaha mikro, kecil dan menengah yang memenuhi definisi dan kriteria usaha mikro, kecil dan menengah sebagaimana diatur dalam UU No. 20 Tahun 2008 tentang UMKM. Berdasarkan UU tersebut, UMKM adalah usaha produktif yang memenuhi kriteria usaha dengan batasan tertentu kekayaan bersih dan hasil penjualan tahunan. Menurut Undang-Undang Republik Indonesia No. 20 tahun 2008, usaha mikro, kecil, dan menengah bertujuan 
untuk menumbuhkan dan mengembangkan usahanya dalam rangka membangun perekonomian nasional berdasarkan demokrasi ekonomi yang berkeadilan.

Kriteria-kriteria UMKM berdasarkan Undang-Undang No. 20 Tahun 2008 Pasal 6, yaitu Usaha Mikro memiliki kekayaan bersih paling banyak Rp 50.000.000,00 (lima puluh juta rupiah) tidak termasuk tanah dan bangunan tempat usaha, atau hasil penjualan tahunan paling banyak Rp 300.000.000,00 (tiga ratus juta rupiah). Usaha Kecil, kekayaan bersih lebih dari Rp 50.000.000,00 (lima puluh juta rupiah) sampai dengan Rp500.000.000,00 (lima ratus juta rupiah) tidak termasuk tanah dan bangunan tempat usaha, atau hasil penjualan tahunan lebih dari Rp 300.000.000,00 (tiga ratus juta rupiah) sampai dengan Rp 2.500.000.000,00 (dua milyar lima ratus juta rupiah). Usaha Menengah memiliki kekayaan bersih lebih dari Rp 500.000.000,00 (lima ratus juta rupiah) sampai dengan $\mathrm{Rp}$ 10.000.000.000,00 (sepuluh milyar rupiah) tidak termasuk tanah dan bangunan tempat usaha, atau hasil penjualan tahunan lebih dari $\mathrm{Rp}$ 2.500.000.000,00 (dua milyar lima ratus juta rupiah) sampai dengan Rp 50.000.000.000,00 (lima puluh milyar rupiah).

\section{METODE PENELITIAN}

\subsection{Metode Penelitian}

Penelitian ini termasuk dalam penelitian asosiatif dengan teknik analisis kuantitatif. Menurut Sugiyono (2003) penelitian asosiatif merupakan penelitian yang bertujuan untuk mengetahui pengaruh ataupun juga hubungan antara dua variabel atau lebih.

Pengambilan sampel penelitian dipilih yang dapat mewakili keuangan inklusif (financial inclusion) dan kredit yang disalurkan pada sektor UMKM di Indonesia dengan pertimbangan ketersediaan data (purposive sampling). Oleh karena itu dipilih sampling 33 provinsi yang ada di Indonesia sehingga diperoleh data mengenai keuangan inklusif dan penyaluran kredit pada sektor UMKM selama tahun 2010-2013 dengan total observasi sebanyak 132 observasi.

\subsection{Sumber Data dan Teknik Pengumpulan Data}

Sumber data yang digunakan dalam studi ini adalah menggunakan data sekunder dengan jenis data panel yang merupakan gabungan data time series dari tahun 2010 2013 dan data cross section 33 provinsi di Indonesia. Teknik pengumpulan data sekunder yang dilakukan adalah diambil dari Badan Pusat Statistik mengenai data kependudukan dan dari Statistik Perbankan Indonesia (SPI) Bank Indonesia atau Otoritas Jasa Keuangan terkait data keuangan. Adapun jenis data yang dikumpulkan seperti dibawah ini : 
Tabel 1. Jenis Data yang Dikumpulkan

\begin{tabular}{clc}
\hline No & \multicolumn{1}{c}{ Data } & Sumber \\
\hline 1 & Penduduk dewasa (15+) per Provinsi thn 2010-2013 & BPS \\
2 & Jumlah Kantor Cabang Bank per Provinsi thn 2010-2013 & SPI \\
3 & Jumlah Dana Pihak Ketiga per Provinsi thn 2010-2013 & SPI \\
4 & Jumlah Kredit yang disalurkan per Provinsi thn 2010-2013 & SPI \\
5 & Jumlah Kredit yang disalurkan pada sektor UMKM per & SPI \\
& Provinsi thn 2010-2013 & \\
6 & Jumlah kredit bermasalah kolektibilitas 3,4, dan 5 per provinsi & SPI \\
& thn 2010-2013 & \\
\hline
\end{tabular}

\subsection{Metode Analisis}

Model dalam penelitian ini sebagai berikut :

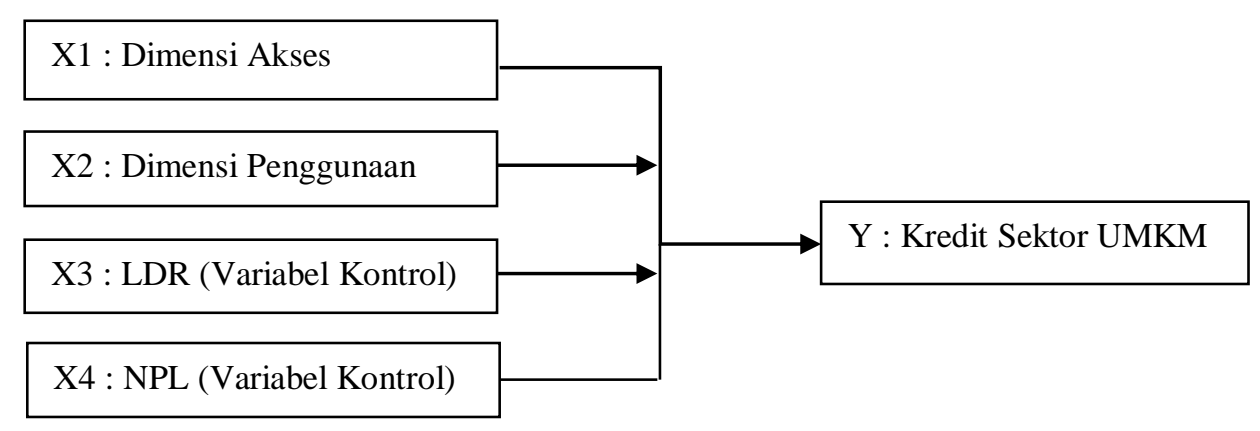

\section{Gambar 1. Model Penelitian}

Dari model diatas, yang menjadi variabel independen adalah dimensi akses terhadap perbankan (X1) dan dimensi penggunaan dari layanan perbankan (X2), sebagai variabel kontrol digunakan LDR (X3) dan NPL (X4) sedangkan kredit yang disalurkan pada sektor Usaha Mikro Kecil dan Menengah (UMKM) sebagai variabel terikat. Rumusan hipotesis penelitian untuk variabel X1 adalah H1 : "Diduga ada pengaruh yang signifikan antara keuangan inklusif (dimensi akses bank) terhadap kredit yang disalurkan pada sektor UMKM di Indonesia." Sedangkan variabel X2 yakni H1 : "Diduga ada pengaruh yang signifikan antara keuangan inklusif (dimensi penggunaan layanan bank) terhadap kredit yang disalurkan pada sektor UMKM di Indonesia."

Berdasarkan beberapa penelitian terdahulu menyebutkan bahwa perilaku penawaran kredit perbankan dipengaruhi seperti NPL (Warjiyo, 2004). NPL UMKM salah satu faktor yang mempengaruhi penawaran kredit perbankan kepada UMKM (Nurhidayat, 2010). Sehingga alasan tersebut membuat penulis mengambil variabel LDR dan NPL sebagai variabel kontrol penelitian ini 


\subsubsection{Akses}

Penulis menggunakan jumlah kantor cabang bank per 100.000 penduduk dewasa saja. Alasannya ketersediaan data dan kantor cabang menurut penulis adalah yang utama dalam dimensi akses sebelum keberadaan yang lain (atm, dll). Sehingga formulanya (Bank Indonesia, 2013) :

Dimensi Akses $=\frac{\text { EKantor Bank }}{\Sigma P_{\text {enduduk Dewasa }}} \times 100.000$

Keterangan :

Penduduk Dewasa : Penduduk usia 15 tahun keatas

\subsubsection{Penggunaan (Usage)}

Karena tidak didapati data penyajian di Statistik Perbankan Indonesia mengenai jumlah rekening tiap provinsi, maka penulis menggunakan jumlah dana pihak ketiga per penduduk dewasa saja tanpa melihat jumlah rekening kredit, dengan pertimbangan setiap pemohon kredit yang disetujui otomatis wajib membuka rekening tabungan atau lainnya sebagai rekening untuk pembayaran angsuran atau kegunaan lain. Sehingga penduduk dewasa yang mendapat kredit pun sudah terwakili dengan melihat data dana pihak ketiga. Formulanya adalah (Bank Indonesia, 2013) :

Dimensi Penggunaan $=\frac{\Sigma D P K}{\sum P_{\text {enduduk Dewasa }}}$

Keterangan :

DPK : Dana Pihak Ketiga (giro,tabungan, dan deposito masyarakat di perbankan)

Penelitian ini menggunakan variabel kontrol LDR (Loan to Deposit Ratio) dan NPL (Non Performing Loan). Loan to Deposit Ratio (LDR) menurut Surat Edaran Bank Indonesia No 6/23/DPNP tanggal 31 Mei 2004 adalah rasio kredit yang diberikan terhadap dana pihak ketiga (giro, tabungan, sertifikat deposito, dan deposito). Semakin tinggi LDR pada suatu bank menunjukkan semakin besar pula dana pihak ketiga yang disalurkan menjadi kredit maka akan mengakibatkan semakin rendahnya likuiditas bank tersebut karena jumlah dana yang diperlukan untuk membiayai kredit menjadi semakin besar, sebaliknya jika semakin rendah LDR pada suatu bank maka akan mengakibatkan semakin tingginya likuiditas bank yang bersangkutan. LDR juga merupakan indikator fungsi intermediasi perbankan. Semakin besar LDR berarti kredit yang tersalurkan juga semakin besar atas dana masyarakat yang dihimpun. Adapun rumus LDR dibawah ini : 


$$
L D R=\frac{\Sigma \text { Kredit }}{\Sigma \text { Dana Pihak Ketiga }} \times 100 \%
$$

Keterangan:

Kredit : Pinjaman yang disalurkan perbankan

Dana Pihak Ketiga : Gabungan dari giro, tabungan, dan deposito masyarakat

LDR : Rasio kredit terhadap dana pihak ketiga

NPL mencerminkan risiko kredit, semakin kecil NPL semakin kecil pula risiko kredit yang ditanggung pihak bank. Klasifikasi tentang kualitas kredit dapat dilihat PBI No.14/15/PBI/2012 tentang Penilaian Kualitas Aset Bank Umum dan SE BI No.7/3/DPN tanggal 31 Januari 2005 perihal Penilaian Kualitas Aktiva Bank Umum beserta lampirannya. Berdasarkan Surat Edaran Bank Indonesia No. 6/23/DPNP tanggal 31 Mei 2004 NPL dirumuskan sebagai berikut:

$N P L=\frac{\text { Kredit Kurang Lancar+KreditDiragukan+Kredit Macet }}{\text { Totak Kredit }} \times 100 \%$

Setelah menentukan variabel menjadi variabel bebas dan yang menjadi variabel terikat maka berikutnya adalah menentukan model regresi data panel terbaik. Menurut Widarjono (2007), ada tiga uji untuk memilih teknik estimasi data panel. Pertama, uji statistik $\mathrm{F}$ digunakan untuk memilih antara metode commom effect atau metode fixed effect. Kedua, uji Hausman yang digunakan untuk memilih antara metode fixed effect atau metode random effect. Ketiga, uji lagrange multiplier (LM) digunakan untuk memilih antara metode commom effect atau metode random effect. Runtutan uji model regresi diringkas dalam Gambar 2, adapun penjelasannya sebagai berikut: (1) Untuk menentukan Fixed Effect Model (FEM) atau Common Effect Model (CEM), langkah awal melakukan uji statistik F (Uji Chow) pada regresi yang dihasilkan oleh model FEM. Hipotesisnya adalah $\mathrm{H0}$ : diterima, jika cross section $\mathrm{F}$ memiliki p-value > 5\% maka CEM lebih baik. Alternatifnya, H0 : ditolak, jika cross section F memiliki p-value $<5 \%$ maka FEM lebih baik. (2) Apabila hasil uji F diperoleh kesimpulan H0 ditolak, yang berarti FEM lebih baik maka selanjutnya FEM ini diperbandingkan dengan random effect model (REM). Uji yang diterapkan adalah Uji Hausman. Dengan software Eviews dilakukan uji terhadap hasil regresi dengan REM. Hipotesisnya H0 : diterima, jika cross section random memiliki $\mathrm{p}=$ value $>5 \%$ maka REM lebih baik. Jika H0 : ditolak, maka FEM lebih baik. (3) Uji yang diterapkan untuk mengetahui CEM atau REM yang lebih baik adalah langrange multiplier (LM) yang dikembangkan Breusch-Pagan. Hipotesisnya adalah H0: diterima jika nilai LM hitung < dari nilai kritis Chi-Squares maka CEM yang lebih tepat. Jika sebaliknya maka REM yang lebih tepat. 


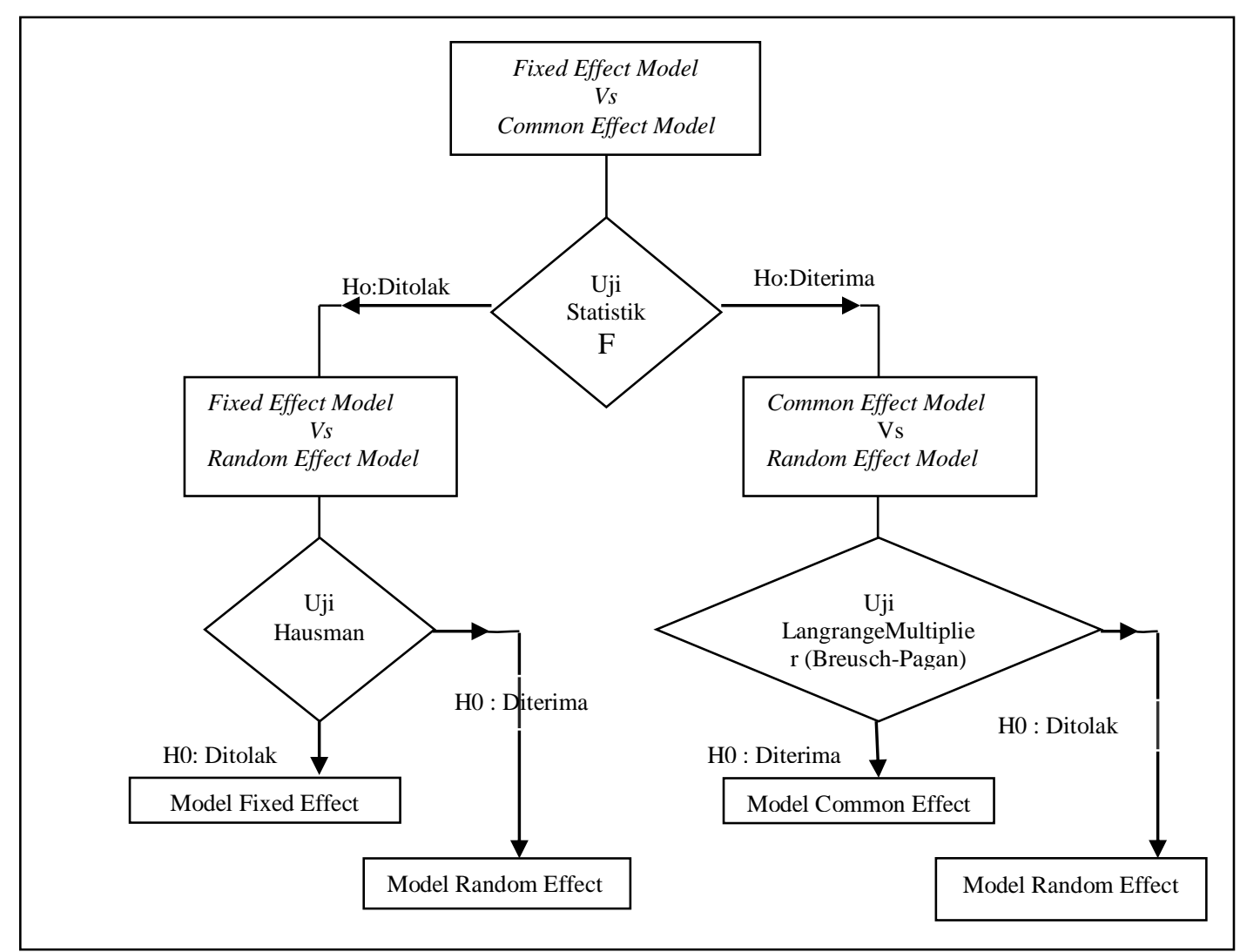

Gambar 2. Alur Tahap Pemilihan Model Regresi Data Panel

\section{PEMBAHASAN}

\subsection{Hasil Uji Model Estimasi}

\subsubsection{Uji Chow (Uji F) : Fixed Effect Model atau Common Effect Model}

Uji F digunakan untuk mengetahui apakah teknik regresi data panel dengan fixed effects lebih baik dari model regresi common effects. Dengan hipotesis :

Fhit < Ftabel H0 : diterima, Model common effects lebih baik

Fhit > Ftabel H0 : ditolak, Model Fixed Effects lebih baik

Adapun hasil regresi kedua model (fixed effects dan common effects) ditunjukkan dalam Tabel 2 berikut ini : 
Tabel 2. Hasil Regresi Common Effects Vs Fixed Effect Model

\begin{tabular}{lll}
\hline Variabel & $\begin{array}{l}\text { Common } \\
\text { Effect }\end{array}$ & $\begin{array}{l}\text { Fixed } \\
\text { Effect }\end{array}$ \\
\hline Prob Value: & & \\
Akses & 0,0001 & 0,2002 \\
Guna & 0,0000 & 0,0001 \\
LDR & 0,3771 & 0,0852 \\
NPL & 0,0000 & 0,4734 \\
RSS & $32.914,12$ & 898,50 \\
Adjust R & 0,427 & 0,978 \\
\hline
\end{tabular}

Dari hasil kedua model di atas terlihat bahwa model common meskipun variabel independennya masing-masing memiliki koefisien yang signifikan berpengaruh terhadap UMKM seperti ditunjukkan oleh probability value akses sebesar 0,0000 dan guna (penggunaan) sebesar 0,0000. Namun Adjusted R-Squared bernilai 0,427 lebih kecil dibandingkan Adj $R$-Squared model fixed effect yang memiliki nilai 0,978. Untuk itu, perlu dilakukan uji Chow (Uji F) dengan rumus F Hitung dibawah ini.

$F$ hitung $=\frac{(\operatorname{RSS} 1-\mathrm{RSS2}) /(\mathrm{n}-1)}{\mathrm{RSS2} /(\mathrm{nT}-\mathrm{n}-\mathrm{k})} \sim \mathrm{F}\left(\alpha_{s}(\mathrm{n}-1) ;(\mathrm{nT}-\mathrm{n}-\mathrm{k})\right)$

Keterangan:

RSS1 : Sum Square Resid regresi Common Model

RSS2 : Sum Square Resid regresi Fixwed Effect Model

Dengan $\mathrm{n}=33, \mathrm{~T}=4, \mathrm{k}=4, \mathrm{RSS} 1=32.914,12 \quad \mathrm{RSS} 2=898,50$

Diperoleh F-Hit $=105,78$

Ftabel $(5 \%):(32,95)=1,565$.

Maka F-Hit > Ftabel : Ho ditolak sehingga model fixed effects lebih baik.

Selain itu, mana model yang lebih baik juga dapat dilihat dari P-Value cross section $\mathrm{F}$ yang dihasilkan melalui eviews (Testing Fixed/Random-Redundant Fiexed Effect Likelihood Ratio).

Tabel 3. Hasil Test Fixed effect (Redundant Fixed Test)

\begin{tabular}{llll}
\hline Effect Test & Statistic & Df & Prob. \\
\hline Cross-section F & 92.643422 & $(32,95)$ & 0.0000 \\
Cross-section Chi Square & 458.325007 & 32 & 0.0000 \\
\hline
\end{tabular}


Tabel 3 menunjukkan P-Value 0,0000 < 0,05 sehingga H0 ditolak, model fixed effects lebih baik. Selanjutnya model fixed effects dibandingkan dengan model random effect.

\subsubsection{Uji Hausman: Fixed Effect Model atau Random Effect Model}

Untuk mengetahui mana yang lebih baik antara model fixed effect dengan random effect, digunakan uji hausman.

Tabel 4. Hasil Uji Model Random dengan Hausman Test

\begin{tabular}{cc}
\hline Test Summary & Cross-Section Random \\
\hline Chi-Sq Statistic & 15.779753 \\
Chi-Sq.df & 4 \\
Prob. & 0.0033 \\
\hline
\end{tabular}

Hasil uji hausman menunjukkan P-value $0,0033<0.05$, sehingga $\mathrm{H} 0$ ditolak dan model yang tepat adalah fixed effect model.

\subsection{Uji Asumsi Klasik}

Penelitian ini telah lolos uji asumsi klasik yakni: uji multikolineritas, uji heteroskedastisitas, dan uji autokorelasi. Khusus uji autokorelasi, lolos setelah dilakukan koreksi model fixed effect dengan cross section weight pada program eviews.

Tabel 5. Hasil Fixed Effect Model dengan Metode Cross Section Weight

\begin{tabular}{lll}
\hline Variabel & Coef & Prob. \\
\hline Prob Value: & & \\
C & 4,113 & 0,0041 \\
Akses & 1,930 & 0,0021 \\
Guna & 0,232 & 0,0000 \\
LDR & 0,032 & 0,0000 \\
NPL & $-0,181$ & 0,2771 \\
Adjust ${ }^{2}$ & 0,985 & \\
F-Statistic & 240,026 & \\
DW-Stat & 1,655 & \\
\hline
\end{tabular}

\subsection{Uji Kelayakan (Goodness of Fit) Regresi Data Panel}

\subsubsection{Uji-F}

Hipotesis uji $\mathrm{F}$ ini adalah :

$\mathrm{H} 0: \mathrm{b} 1=\mathrm{b} 2=. . \mathrm{bk}=0$. Artinya semua variabel independen bukan penjelas yang signifikan terhadap variabel independen. 
$\mathrm{H} 1: \mathrm{b} 1 \neq \mathrm{b} 2 \neq \ldots \neq \mathrm{b} \mathrm{k} \neq 0$. Artinya semua variabel independen penjelas yang signifikan terhadap variabel independen.

Kriterianya:

Jika $F_{\text {hitung }}<$ Ftabel, maka H0 diterima

Jika Fhitung $>$ Ftabel maka H0 ditolak, H1 diterima juga digambarkan dari nilai signifikansi $<0,05$.

Diperoleh F Tabel $=\mathrm{F}(5 \%) ;(\mathrm{v} 1, \mathrm{v} 2)$

$\mathrm{V} 1=\mathrm{m}-1$ dan $\mathrm{V} 2=\mathrm{n}-\mathrm{m} ; \mathrm{m}=$ jumlah variabel independen $=4 ; \mathrm{n}=$ jumlah observasi $=132$. Ftabel $=\mathrm{F}(5 \%) ;(3,128)=2,68$

Hasil Regresi dengan FEM model diperoleh Fhitung= $240>$ Ftabel 2,68 artinya semua variabel independen $($ Akses $=$ Akses Perbankan dan Guna $=$ Penggunaan Layanan Perbankan, LDR=Loan to Deposit Ratio, dan NPL=Non Performing Loan) menjelaskan secara signifikan terhadap variabel dependen (kredit yang disalurkan pada sektor UMKM).

\subsubsection{Uji-t (Uji Parsial)}

Dari hasil regresi model FEM diperoleh sebagai berikut:

Tabel 6. Hasil Statistik Sebelum Adanya Variabel Kontrol

\begin{tabular}{crcccc}
\hline Variabel & Koef & t-hitung & t-tabel & Probabilitas & Hipotesis \\
\hline Akses & 3,61 & 3,15 & 1,66 & 0,000 & H0 ditolak, H1 diterima \\
Guna & 0,22 & 8,04 & 1,66 & 0,000 & H0 ditolak, H1 diterima \\
$\mathrm{R}^{2}$ & 0,9896 & & & & \\
Prob (F-statistic) & 0,0000 & & & & \\
\hline
\end{tabular}

Sebelum adanya variabel kontrol, variabel akses dan variabel guna menunjukkan secara parsial berpengaruh positif signifikan terhadap kredit yang disalurkan pada UMKM. Demikian juga secara simultan (bersama) variabel akses dan guna juga berpengaruh signifikan.

Hasil uji ini menunjukkan bahwa baik variabel akses, guna, dan variabel kontrol LDR masing-masing (parsial) berpengaruh signifikan terhadap variabel dependen UMKM. Sedangkan variabel kontrol NPL secara parsial tidak berpengaruh signifikan terhadap variabel dependen UMKM. Secara simultan dengan keberadaan variabel kontrol juga masih sama hasilnya yaitu berpengaruh signifikan.

Apabila dilihat dari Tabel 6 dan Tabel 7, ada tidaknya variabel kontrol tidak mempengaruhi signifikansi variabel akses dan guna terhadap kredit UMKM karena hasilnya tetap sama. 
Tabel 7. Hasil Statistik Setelah Adanya Variabel Kontrol

\begin{tabular}{cccccc}
\hline Variabel & Koef & t-hitung & t-tabel & Probabilitas & Hipotesis \\
\hline Akses & 1,93 & 3,15 & 1,66 & 0,002 & $\begin{array}{c}\text { H0 ditolak, H1 } \\
\text { diterima }\end{array}$ \\
Guna & 0,23 & 8,04 & 1,66 & 0,000 & $\begin{array}{c}\text { H0 ditolak, H1 } \\
\text { diterima }\end{array}$ \\
LDR & 0,03 & 4,72 & 1,66 & 0,000 & $\begin{array}{c}\text { H0 ditolak, H1 } \\
\text { diterima }\end{array}$ \\
NPL & $-0,18$ & $-1,09$ & 1,66 & 0,277 & H0 diterima \\
$\mathrm{R}^{2}$ & 0,9891 & & & & \\
$\begin{array}{c}\text { Prob (F- } \\
\text { statistic) }\end{array}$ & 0,0000 & & & & \\
\hline
\end{tabular}

\subsubsection{Koefisien Determinasi $\left(\mathbf{R}^{2}\right)$}

Menurut Kuncoro (2011), nilai koefisien determinasi berkisar antara nol dan satu $\left(0<\mathrm{R}^{2}<1\right)$. Nilai $\mathrm{R}^{2}$ yang semakin mendekati 1 artinya variabel independen mampu memberikan hampir semua informasi yang dibutuhkan dalam menjelaskan perubahan variabel dependen.

Koefisien determinasi $\left(\mathrm{R}^{2}\right)$ diperoleh dari regresi model FEM (lihat Tabel 5) yaitu sebesar 0,99 menunjukkan (X1: Akses dan X2: Guna, variabel kontrol X3: LDR, dan variabel kontrol X4: NPL) dalam persamaan regresi ini mampu menjelaskan perubahan variabel independen (UMKM) secara signifikan.

Setelah melalui tahapan memilih model terbaik, lolos uji asumsi klasik, dan lolos uji kelayakan (Goodness of Fit) yang dibuktikan dengan variabel akses perbankan, variabel penggunaan layanan perbankan, variabel kontrol Loan to Deposit Ratio, dan variabel kontrol Non Performing Loan yang berpengaruh signifikan secara simultan terhadap kredit sektor UMKM, untuk uji parsial hanya variabel kontrol NPL yang tidak signifikan maka dapat ditulis persamaan regresinya sebagai berikut :

$\mathrm{Y}_{\mathrm{it}}=\mathrm{X}_{\mathrm{it}} ß+\mathrm{c}_{\mathrm{i}}+\mathrm{e}_{\mathrm{it}}$

$\mathrm{UMKM}=4,11+1,93 \mathrm{Akses}_{\mathrm{it}}+0,23 \mathrm{Guna}_{\mathrm{it}}+0,03 \mathrm{LDR}_{\mathrm{it}}-0,18 \mathrm{NPL}_{\mathrm{it}}+\varepsilon_{\mathrm{it}}$

Keterangan :

UMKM : Kredit yang disalurkan pada Sektor UMKM (dalam Rp Trilyun)

Akses : Jumlah kantor per 100.000 orang dewasa (dalam unit kantor)

Guna : Rasio jumlah DPK per penduduk dewasa (dalam Rp Juta)

LDR : Rasio kredit yang disalurkan perbankan terhadap dana pihak ketiga (\%) sebagai variabel kontrol

NPL : Rasio kredit kolektibilitas 3, 4, 5 terhadap total kredit perbankan (\%) sebagai variabel kontrol 
Selama tahun 2010 sampai 2013 kredit sektor UMKM terus meningkat penyalurannya namun persentase kontribusi kredit sektor UMKM masih lebih kecil dari pada sektor non-UMKM. Porsi kredit UMKM yang disalurkan terhadap total kredit perbankan dapat dilihat pada Tabel 8 berikut :

Tabel 8. Perbandingan Kredit Sektor UMKM terhadap Total Kredit (Trilyun)

\begin{tabular}{|c|c|c|c|c|c|c|c|c|}
\hline \multirow[b]{2}{*}{ Kredit } & \multicolumn{2}{|c|}{2010} & \multicolumn{2}{|c|}{2011} & \multicolumn{2}{|c|}{2012} & \multicolumn{2}{|c|}{2013} \\
\hline & Nominal & Persen & Nominal & Persen & Nominal & Persen & Nominal & Persen \\
\hline $\begin{array}{l}\text { Sektor UMKM } \\
\text { Sektor Non- }\end{array}$ & 445,505 & $20,7 \%$ & 458,164 & $20,8 \%$ & 526,397 & $19,4 \%$ & 608,823 & $18,5 \%$ \\
\hline UMKM & $1.705,368$ & $79,3 \%$ & $1.741,930$ & $79,2 \%$ & $2.181,465$ & $80,6 \%$ & $2.684,051$ & $81,5 \%$ \\
\hline Total Kredit & $2.150,873$ & $100 \%$ & $2.200,094$ & $100 \%$ & $2.707,862$ & $100 \%$ & $3.292,874$ & $100 \%$ \\
\hline
\end{tabular}

Daerah-daerah dengan pertumbuhan kredit UMKM tertinggi 2010-2013 didominasi oleh provinsi-provinsi di kawasan Indonesia Timur (Papua Barat, Nusa Tenggara Barat, Kepulauan Riau, Kalimantan Barat, dan Sulawesi Tenggara). Meskipun secara nominal kredit UMKM masih lebih besar di pulau Jawa (Jawa Timur, Jawa Tengah, Jawa Barat dan termasuk DKI Jakarta), hanya satu di luar pulau Jawa yakni Sumatera Utara (Tabel 9 halaman 15).

\subsection{Pengaruh Dimensi Akses Terhadap Sektor UMKM}

Dimensi ini merupakan rasio jumlah kantor cabang bank per 100.000 penduduk dewasa usia 15 tahun keatas. Dari data tahun 2010-2013 diperoleh rata-rata jumlah kantor cabang sebanyak 2 unit untuk melayani 100.000 orang dewasa di Indonesia. Mengacu pada data 2013, daerah yang memiliki rasio 5 tertinggi adalah Kepulauan Riau $(8,81)$, DKI Jakarta $(7,63)$, Papua Barat $(4,79)$, Kalimantan Timur $(4,21)$ dan Sulawesi Utara $(3,28)$. Sedangkan daerah yang rasio rendah lima terbawah adalah Lampung $(1,02)$, Banten $(1,16)$, Jawa Barat $(1,20)$, Jawa Tengah $(1,32)$, dan Jawa Timur $(1,45)$.

Berdasarkan hasil yang diperoleh selama kurun waktu 2010-2013, dimensi akses perbankan berpengaruh positif dan signifikan terhadap kredit yang disalurkan pada sektor usaha mikro kecil dan menengah (UMKM) di Indonesia. Bank akan mudah di akses oleh UMKM apabila keberadaannya tersebar merata sehingga dapat dicapai oleh UMKM yang berada di pelosok-pelosok. Bank dimanfatkan oleh UMKM untuk akses permodalan, menyimpan dana, untuk sarana transaksi transfer dana masuk dan transfer dana keluar. Dari apa yang telah dipaparkan diatas, menunjukkan bahwa perkembangan kredit yang disalurkan pada sektor UMKM tidak terlepas dari kemudahan UMKM untuk mengakses lembaga keuangan, dalam penelitian ini dimaksudkan lembaga keuangan formal (perbankan). Kemudahan akses tersebut muncul terutama karena dua hal, yakni pertama karena adanya jaringan kantor dan layanan disekitar UMKM tersebut 
beraktivitas dan kedua karena kemudahan (kebijakan) memperoleh modal dari perbankan.

Tabel 9. Pertumbuhan Kredit Sektor UMKM 2010 s.d 2013 (Rp Trilyun)

\begin{tabular}{|c|c|c|c|c|c|c|c|}
\hline No & Provinsi & 2010 & 2011 & 2012 & 2013 & $\begin{array}{l}\text { Growth } \\
2010 \text { ke } \\
2013\end{array}$ & $\begin{array}{l}\text { Rerata } \\
\text { Growth } \\
\text { /thn }\end{array}$ \\
\hline 1 & Papua Barat & 1,750 & 1,181 & 2,523 & 3,376 & $93 \%$ & $23 \%$ \\
\hline 2 & Nusa Tenggara Barat & 3,540 & 3,820 & 5,175 & 6,318 & $79 \%$ & $20 \%$ \\
\hline 3 & Kepulauan Riau & 4,411 & 4,648 & 5,514 & 7,402 & $68 \%$ & $17 \%$ \\
\hline 4 & Kalimantan Barat & 6,548 & 6,910 & 8,350 & 10,673 & $63 \%$ & $16 \%$ \\
\hline 5 & Sulawesi Tenggara & 2,808 & 2,871 & 3,715 & 4,516 & $61 \%$ & $15 \%$ \\
\hline 6 & Papua & 4,736 & 4,750 & 5,477 & 7,471 & $58 \%$ & $14 \%$ \\
\hline 7 & Bali & 12,708 & 13,050 & 16,356 & 19,951 & $57 \%$ & $14 \%$ \\
\hline 8 & Nusa Tenggara Timur & 2,635 & 2,624 & 3,297 & 4,127 & $57 \%$ & $14 \%$ \\
\hline 9 & DI Yogyakarta & 5,409 & 5,413 & 6,549 & 8,431 & $56 \%$ & $14 \%$ \\
\hline 10 & Kep. Bangka Belitung & 1,932 & 2,225 & 2,604 & 2,990 & $55 \%$ & $14 \%$ \\
\hline 11 & Banten & 14,966 & 16,026 & 18,863 & 22,631 & $51 \%$ & $13 \%$ \\
\hline 12 & Sulawesi Barat & 1,275 & 1,326 & 1,567 & 1,875 & $47 \%$ & $12 \%$ \\
\hline 13 & Jawa Tengah & 42,767 & 43,721 & 51,576 & 62,679 & $47 \%$ & $12 \%$ \\
\hline 14 & Kalimantan Selatan & 6,170 & 6,242 & 8,086 & 8,914 & $44 \%$ & $11 \%$ \\
\hline 15 & Sumatera Selatan & 12,177 & 12,190 & 14,807 & 17,506 & $44 \%$ & $11 \%$ \\
\hline 16 & Sumatera Barat & 8,352 & 8,721 & 10,663 & 11,804 & $41 \%$ & $10 \%$ \\
\hline 17 & Jawa Barat & 55,806 & 58,034 & 67,636 & 78,774 & $41 \%$ & $10 \%$ \\
\hline 18 & Sumatera Utara & 26,204 & 26,707 & 31,470 & 36,947 & $41 \%$ & $10 \%$ \\
\hline 19 & Jambi & 6,299 & 6,724 & 7,809 & 8,772 & $39 \%$ & $10 \%$ \\
\hline 20 & Bengkulu & 2,967 & 3,115 & 3,598 & 4,103 & $38 \%$ & $10 \%$ \\
\hline 21 & Gorontalo & 1,464 & 1,701 & 1,820 & 2,011 & $37 \%$ & $9 \%$ \\
\hline 22 & Lampung & 8,495 & 9,060 & 10,276 & 11,664 & $37 \%$ & $9 \%$ \\
\hline 23 & Sulawesi Selatan & 17,206 & 17,926 & 19,460 & 23,596 & $37 \%$ & $9 \%$ \\
\hline 24 & Sulawesi Tengah & 4,881 & 5,183 & 5,559 & 6,595 & $35 \%$ & $9 \%$ \\
\hline 25 & Kalimantan Tengah & 3,588 & 3,590 & 4,433 & 4,837 & $35 \%$ & $9 \%$ \\
\hline 26 & Kalimantan Timur & 14,916 & 15,118 & 17,295 & 20,018 & $34 \%$ & $9 \%$ \\
\hline 27 & Riau & 13,502 & 13,995 & 16,096 & 17,968 & $33 \%$ & $8 \%$ \\
\hline 28 & Maluku Utara & 1,122 & 1,204 & 1,327 & 1,474 & $31 \%$ & $8 \%$ \\
\hline 29 & Jawa Timur & 61,621 & 62,346 & 65,980 & 79,322 & $29 \%$ & $7 \%$ \\
\hline 30 & DKI Jakarta & 79,858 & 82,225 & 93,051 & 95,185 & $19 \%$ & $5 \%$ \\
\hline 31 & Maluku & 1,746 & 1,756 & 1,808 & 2,000 & $15 \%$ & $4 \%$ \\
\hline 32 & Aceh & 6,226 & 5,850 & 6,395 & 7,026 & $13 \%$ & $3 \%$ \\
\hline 33 & Sulawesi Utara & 6,141 & 5,929 & 5,861 & 6,431 & $5 \%$ & $1 \%$ \\
\hline
\end{tabular}

Sumber : Statistik Perbankan Indonesia, (BI, 2010-2013) dengan Diolah

\subsection{Pengaruh Dimensi Penggunaan Terhadap Sektor UMKM}

Berdasarkan hasil yang diperoleh selama kurun waktu 2010-2013, dimensi penggunaan layanan perbankan berpengaruh positif dan signifikan terhadap sektor usaha mikro kecil dan menengah (UMKM) di Indonesia. Dimensi ini diwakili oleh rasio jumlah dana pihak ketiga di perbankan terhadap jumlah penduduk usia dewasa $(+15$ tahun). Hasil rasio ini menunjukkan bahwa lima provinsi teratas di Indonesia dalam hal jumlah dana pihak ketiga (baik berupa tabungan, giro, maupun deposito) per penduduk dewasanya adalah provinsi DKI Jakarta (Rp 245 juta/penduduk), Kepulauan Riau (Rp 58,28 juta/penduduk), Kalimantan Timur (Rp 32,74 juta/penduduk), Bali (Rp 21,11 juta/penduduk), dan Papua Barat (Rp 19,33 juta/penduduk). Sedangkan lima provinsi terendah dalam hal rasio ini yakni Sulawesi Barat (Rp 3,44 juta/penduduk), Gorontalo 
(Rp 3,99 juta/penduduk), Nusa Tenggara Barat (Rp 4,41 juta/penduduk), Lampung (Rp 4,52 juta/penduduk), dan Nusa Tenggara Timur (Rp 15,5 juta/penduduk).

Menurut Kasmir (2004), jumlah dana pihak ketiga berbanding positif terhadap jumlah kredit yang disalurkan, sebab semakin meningkat jumlah dana pihak ketiga yang berhasil dihimpun yang berasal dari tabungan dan deposito maka kemampuan bank untuk menyalurkan kredit juga semakin meningkat.

Penelitian lain menunjukkan hal sama seperti "dana pihak ketiga berpengaruh positif dan signifikan terhadap penyaluran kredit” (Suryawati, Cipta, Susila \& Agus 2014), "Variabel internal (CAR, Dana Pihak Ketiga, NPL UMKM dan ROA) dan variabel eksternal (SBI dan Inflasi) secara bersama-sama dan signifikan mempengaruhi bank persero, bank umum swasta nasional, bank pembangunan daerah serta bank asing dan campuran dalam memberikan penawaran kredit terhadap sektor UMKM" (Nurhidayat, 2010).

Terkait dengan Peraturan Bank Indonesia yang berlaku saat itu yakni Peraturan Bank Indonesia Nomor 12/19/Pbi/2010 tentang Giro Wajib Minimum Bank Umum Pada Bank Indonesia Dalam Rupiah Dan Valuta Asing Pasal 10 Ayat 1.A menyebutkan batas bawah LDR target sebesar 78\% (tujuh puluh delapan persen) dan ayat 1.b Batas Atas LDR target sebesar 100\% yang sudah diubah dengan PBI No 15/7/PBI/2013 tentang Perubahan Kedua Atas Peraturan Bank Indonesia Nomor 12/19/Pbi/2010 tentang Giro Wajib Minimum Bank Umum Pada Bank Indonesia dalam Rupiah dan Valuta Asing. Perubahan Peraturan PBI ini terutama pada ketentuan batas atas LDR target sebesar 92\% berlaku sejak 2013. Ketentuan tersebut dapat mempengaruhi bank-bank dalam penyaluran kredit secara umum. Karena, jika LDR tidak sesuai dengan target yaitu antara 78\% - 100\% untuk PBI tahun 2010 dan saat ini 78\% - 92\% berlaku sejak 2013, maka bank akan dikenakan disinsentif oleh Bank Indonesia berupa ketentuan Giro Wajib Minimum LDR.

Hasil penelitian ini menunjukkan baik sebelum maupun sesudah adanya variabel kontrol LDR dan NPL, pengaruh prediktor utama akses perbankan dan penggunaan layanan bank terhadap kredit yang disalurkan pada sektor UMKM sama yakni tetap positif dan signifikan. Variabel kontrol LDR secara bersama-sama dengan variabel lain turut berpengaruh positif signifikan terhadap variabel dependen UMKM. Hal ini sesuai dengan bukti empiris sebelumnya. Sebaliknya NPL, secara parsial atau secara bersamasama dengan akses dan penggunaan layanan perbankan tidak mempengaruhi kredit yang disalurkan pada UMKM. Hal ini bertentangan dengan teori yang mengungkapkan bahwa perilaku penawaran kredit perbankan dipengaruhi seperti NPL (kredit macet) (Warjiyo, 2004), NPL UMKM salah satu faktor yang mempengaruhi penawaran kredit perbankan kepada UMKM (Nurhidayat, 2010). Namun hasil empiris variabel NPL ini bersesuaian dengan penelitian Suryawati at.al (2014) bahwa NPL tidak berpengaruh dan tidak signifikan terhadap jumlah penyaluran kredit pada LPD Desa Pakraman Pemaron. Temuan penelitian ini juga didukung temuan empirik dari Fransisca dan Hasan Sakti 
Siregal (2007) dan Budiawan (2008) dalam Suryawati at. al (2014), bahwa NPL tidak dapat digunakan untuk memprediksi volume kredit dan hasil penelitian Tito Adhitya Galih (2011) dalam Suryawati at. al (2014) juga menunjukkan bahwa Non Performing Loan tidak berpengaruh signifikan terhadap jumlah penyaluran kredit.

\section{KESIMPULAN}

Dari hasil pembahasan maka diambil simpulan bahwa dimensi akses perbankan secara uji parsial (uji-t) berpengaruh positif dan signifikan terhadap kredit yang disalurkan pada sektor Usaha Mikro, Kecil, dan Menengah (UMKM) di Indonesia, maknanya semakin banyak jaringan kantor bank maka semakin besar kredit yang terserap pada sektor UMKM.

Kedua, dimensi penggunaan layanan perbankan secara parsial berpengaruh positif dan signifikan terhadap kredit yang disalurkan pada sektor UMKM (Uji-t), artinya semakin besar penggunaan layanan bank dalam hal ini menyimpan dananya di bank (DPK), maka semakin besar pula petumbuhan kredit pada sektor UMKM ini.

Penelitian ini menggunakan variabel kontrol LDR dan NPL yang menunjukkan bahwa LDR secara bersama-sama dengan variabel akses dan variabel penggunaan layanan perbankan berpengaruh positif signifikan. Sedangkan NPL mempunyai arah negatif namun tidak signifikan.

\section{DAFTAR PUSTAKA}

Bank Indonesia. (2004). Surat Edaran Bank Indonesia No. 6/23/DPNP perihal Sistem Penilaian Tingkat Kesehatan Bank Umum Tanggal 31 Mei 2004. Diakses dari http://www.bi.go.id/peraturan/perbankan/Documents/0151b17420f84d118de8fdf 0c0642730se623dpnp.pdf.

Bank Indonesia. (2005). Surat Edaran Bank Indonesia No.7/3/DPNP perihal Kualitas Aktiva Bank Umum tanggal 31 Januari 2005. Diakses dari http://www.bi.go.id.

Bank Indonesia. (2012). Peraturan Bank Indonesia No.14/15/PBI/2012 tentang Penilaian Kualitas Aset Bank Umum tanggal 24 Oktober 2012. Diakses dari http://www.bi.go.id/peraturan/pages/pbi_141512.aspx.

Bank Indonesia. (2013). Indeks Keuangan Inklusif. Diakses dari http://www.bi.go.id/ perbankan / keuanganinklusif / indikator / indeks / contents/ default.aspx.

Bank Indonesia. (2015). Statistik Perbankan Indonesia. Diakses dari http://www.bi.go.id/perbankan/indonesia/pages/spi_0114.aspx. 
Camara \& Tuesta. (2014). Measuring Financial Inclusion: A Multidimensional Index. BBVA Research. Working Paper. WP/14/26. Madrid.

Kasmir. (2004). Bank dan Lembaga Keuangan Lainnya. Jakarta : PT. Raja. Grafindo Persada.

Kelkar, V. (2010). Financial Inclusion for Inclusive Growth. ASCI Journal of Management, 55-68.

Kementerian PPN/Bappenas, Badan Pusat Statistik, United Nations Population Funds. Jakarta. (2013). Proyeksi Penduduk Indonesia 2010-2035. Diakses dari http://indonesia.unfpa.org/application/assets/publications/PROYEKSI 2010 2035_Bilingual.pdf.

Kuncoro, M. (2011). Metode Kuantitatif: Teori dan Aplikasi untuk Bisnis dan Ekonomi. Yogyakarta: UPP STIM YKPN.

Nurhidayat. (2010). Analisis Pengaruh Variabel Internal dan Eksternal Perbankan terhadap Penawaran Kredit Sektor UMKM Pada Bank Umum Periode 20072009. Tesis. Magister Manajemen. Universitas Gunadarma Jakarta.

Sarma, M. (2012). Index of Financial Inclusion - A Measure of Financial sector inclusiveness. Money, Trade, Finance, and Development Competence Centerin cooperation with DAAD Partnership and Hochschule für Technik und Wirschaft Berlin University of Applied Sciences. Working Paper No.07/2012. Berlin.

Sugiyono. (2003). Metode Penelitian Bisnis. Cetakan Kelima. Bandung: Alfabeta.

Suryawati, A, N., Cipta., Susila, \& Agus J., (2014). Analisis Pengaruh Dana Pihak Ketiga (DPK), Capital Adequacy Ratio (CAR), Non Performing Loan (NPL), dan Loan to Deposit Ratio (LDR) terhadap Jumlah Penyaluran Kredit (Studi Kasus Pada LPD Desa Pakraman Pemaron Periode 2010-2013). E-Journal Bisma Universitas Pendidikan Ganesha Jurusan Manajemen, Volume 2. Jurusan Manajemen Universitas Pendidikan Ganesha. Singaraja.

Undang-Undang No. 20 Tahun 2008 tentang Usaha Mikro, Kecil dan Menengah.

Warjiyo, P. (2004). Mekanisme Transmisi Kebijakan Moneter di Indonesia. Jakarta: Pusat Pendidikan dan Studi Kebanksentralan BI.

Widarjono, A. (2007). Ekonometrika Teori dan Aplikasi. Yogyakarta: Ekonisia FE UII. 